Original Research Article

\title{
Ecological notes on roosts of Pteropus Giganteus (Brunnich, 1782) in eastern Vidarbha, Maharashtra
}

Bhandarkar, Sudhir V. ${ }^{1}$ and Paliwal, Gopal T. ${ }^{2}$

${ }^{1}$ Manoharbhai Patel College of Arts, Com. \& Science, Deori, Dist. Gondia, Maharashtra, India

${ }^{2}$ S. S. Jaiswal College, Arjuni Morgaon Dist. Gondia, Maharashtra, India

Corresponding Author: sudhirsense@gmail.com

\section{A R T I C L E I N F O}

Received: 05 February 2018 | Accepted: 22 April 2018 | Published Online: 15 August 2018

DOI: $10.31786 / 09756272.18 .9 .1 .110$

EOI: 10.11208/essence.18.9.1.110

Article is an Open Access Publication.

This work is licensed under Attribution-Non Commercial 4.0 International

(https://creativecommons.org/licenses/by/4.0/)

CThe Authors (2018). Publishing Rights @ MANU_ICMANU \& ESSENCE_IJERC.

\section{A B S T R A C T}

The Eastern part Vidarbha in Maharashtra state is sheltered by dense forest vegetation. It is enriched with massive amount of biodiversity of flora and fauna. The populations of Pteropus giganteus are found in a choice of places; they play a crucial role as forest pollinators and seed dispersers. As per IUCN (2008) listed as Least Concern. It is listed as vermin in Schedule V of the Indian Wildlife (Protection) Act. This species is listed on Appendix II of CITES meaning it is not currently threatened but could become so if protective measures are not taken. There is no official protection for Indian flying foxes in India. The roosts near the human habitat has found in immense risk of survival in their conventional camps. The present study was intended to recognize an assortment of roosting trees and surrounding ecological conditions of Indian flying foxes .

\section{K E Y W O R D S}

Ecology | Roosts | Indian Flying Foxes | Threats | Conservation

\section{I T A T I O N}

Bhandarkar, Sudhir V. and Paliwal, Gopal T. (2018): Ecological notes on roosts of Pteropus Giganteus (Brunnich, 1782) in eastern Vidarbha Maharashtra India. ESSENCE Int. J. Env. Rehab. Conserv. IX (1): $67-70$. 


\section{Introduction}

The Indian flying foxes (fruit bat) are flying mammals with amazing ecological and economic importance throughout forest. India has 12 species of flying foxes, among them Pteropus gigantius are frequent in eastern Maharashtra. These are found on the bulky trees nearby villages. They spend daytime in sleeping, resting and grooming each other. At dusk, they fly off together to feed. Their good senses of smell and sight locate ripe fruit sources. After hours spent feeding, resting and digesting, they return to the colony at dawn. They provide vital role as forest pollinators and seed dispersers for the safeguarding and reestablishments of tropical forest diversity. They act as 'Key stone species' and stay the ecosystem in equilibrium. In spite of the high beneficial role of bats, in India they still have a negative public image. They are maltreated because of unawareness about their life history, behavior and their role in ecosystem. They are greatly susceptible to environmental disruption and the species has declined severely in response to anthropogenic activity. They are increasingly in threat locally by cutting down of roosting trees because of road development or other purposes. The species is also hunted in a number of locations for meat and for medicine. Many roost populations appear to be in severe decline. Several studies are carried out in eastern Vidarbha of Maharashtra by Bhandarkar and Paliwal (2013 a,b; 2014, 2017)

\section{Material and Method}

Direct roost count method was followed to estimate the population size of the colony. The population was counted prior to evening flight. In monsoon it was easy to count all the bats prior to evening flight. Most of the observations were done with the naked eyes. Binoculars were used to spot out the bats. Name of the roost trees, surrounding environment, threats and some anecdotal information about the roosts gathered from the villagers. The nature of the present study was conducted to record the roosts of Indian Flying fox and its ecological status.

\section{Result and Discussion}

Over 200 species of flying foxes are distributed throughout the tropics and being frugivorous they play major role in pollination and seed dispersal (Mistry, 2000). Pteropus giganteus is a biggest flying mammal in India. It can be effortlessly identified by its elongated snout, fine developed nostrils and long black ears. In the present exploration, Pteropus giganteus roosts were observed and recorded usually sited in larger trees such as Mangifera indica, Ficus riligiosa, Eucalyptus spp, Arjuna terminalia, Ficus benghalensis, Terminalia arjuna, Tamarindus indica. The colonies of Pteropus giganteus generally located in close proximity of water bodies, close association with human beings near villages. Pteropus giganteus roosts in trees and usually associated with forest fragments or linear patches of vegetation alongside the water bodies. A total of 5065 individuals were recorded in 15 colonies of $P$. giganteus. The colony size ranged from 45 to 1500 individuals of Pteropus giganteus. Out of 15 colonies, sum of 10 colonies were located nearby water bodies and rest of them located closest to agricultural field, road side and residential area. Pteropus giganteus selected larger and taller trees such as Mangifera indica, Ficus riligiosa, Eucalyptus spp, Ficus benghalensis, Terminalia arjuna, Tamarindus indica. The probable reasons for selection of above roost trees are due to long lasting and stable nature. Further, the tall trees in fine uncovered areas may maintain their flights during take-off and landing. All the details of roosting sites, their ID, Name of roosting trees and Number of bats is mentioned in the Table No. 1 and the ecological notes and threats is mentioned in the table no. 2 . Roosting sites of the Indian Flying fox is situated near water bodies and the villages nearby jungles. They always found near human proximity therefore their habitat require such type of environment but due to increasing population the roosting sites come under threats through direct interference by human surrounding the roost. There may be chances to cut the native trees due to ownership of the tree. Ones their habitat destroyed by any cause their breeding habits affected, results in declination of their population, therefore it is important to conserve their original roosting areas and fi- 
ESSENCE_-IJERC | Sudhir and Gopal (2018) | IX (1): 67—70

\begin{tabular}{|c|c|c|}
\hline S. No. & Place of Roost & Ecological notes and Threats \\
\hline 1 & $\begin{array}{l}\text { Mangali Bandh, } \\
\text { Dist. Bhandara }\end{array}$ & $\begin{array}{l}14 \text { trees of Mangifera indica in Amrai situated at farmland and roadside recorded in 2014, } \\
\text { Trees now cut down by owners of farmland, and colony is disturbed by road side activities. }\end{array}$ \\
\hline 2 & $\begin{array}{l}\text { Usgaon Chandori, } \\
\text { Dist. Bhandara }\end{array}$ & $\begin{array}{l}\text { This roost is always found near lake and road, disturbed by regular traffic activities, villagers } \\
\text { also used crackers to put to flight due to their noisy sound. Farmer can cut the roosting trees in } \\
\text { future. Evidences happened for poaching. Usually found Electrocution. }\end{array}$ \\
\hline 3 & $\begin{array}{l}\text { Ashok Lay Land, } \\
\text { Gadegaon, Dist. } \\
\text { Bhandara }\end{array}$ & $\begin{array}{l}\text { Ashok Lay-Land is a leading Truck manufacture Company, spreads in an average area of } \\
\text { about } 300 \text { acre. Total } 37 \text { (2014) bats were present on the giant Nilgiri tree (Eucalyptus), an } \\
\text { evergreen tropical tree near a pond. The site had dense vegetation and wet-land which is suit- } \\
\text { able for their conservation. }\end{array}$ \\
\hline 4 & $\begin{array}{l}\text { Bodra Lake Bodra, } \\
\text { Dist. Bhandara }\end{array}$ & $\begin{array}{l}\text { Bodra place situated near the lake; the site is at another end with dense vegetation of Mango } \\
\text { trees. This site has only } 45 \text { pteropus. Took history from some villagers, they were not inter- } \\
\text { ested about them, but according to some old villagers, there were many more bats before a } \\
\text { decade. Less disturbed place. }\end{array}$ \\
\hline 5 & $\begin{array}{l}\text { Police Station, } \\
\text { Pouni, Dist. Bhan- } \\
\text { dara }\end{array}$ & $\begin{array}{l}\text { Bats were present at the Nilgiri and Akash neem tree at Police Station compound at Pouni. } \\
\text { About } 345 \text { Pteropus bat were present entangled on trees. The roost harbors abundantly on } \\
\text { bareheaded tree. The roost is situated in market near Bhai Lake. The colony is disturbed by } \\
\text { daily activities in market and station. }\end{array}$ \\
\hline 6 & $\begin{array}{l}\text { Shantinagar Lake, } \\
\text { Bhandara }\end{array}$ & $\begin{array}{l}\text { The giant roost located on impoundment on Shantinagar Lake near Pragati colony in Bhandara } \\
\text { city. The roost is on two old mango trees from last } 50 \text { years. The site is not much densely cov- } \\
\text { ered by vegetation and the lake was completely dried and may be a dead Lake, a small water } \\
\text { pool found on the other side. The construction of a building was going on near the site. In } \\
\text { future the roost may completely eliminate due to the close construction of roost. It is found } \\
\text { that the people of Shantinagar sometime torture them to leave this place. But due to the moti- } \\
\text { vation by us, they understand the significance of bat; they will try to motivate others to ovoid } \\
\text { torturing bats. }\end{array}$ \\
\hline 7 & $\begin{array}{l}\text { Pimpalgaon Kohali } \\
\text { Dist. Bhandara }\end{array}$ & $\begin{array}{l}\text { Some agriculture disturbances might be due to agricultural activities. The roost has been pre- } \\
\text { sent last from } 20 \text { years. No special threat found for this site. }\end{array}$ \\
\hline 8 & $\begin{array}{l}\text { Chincholi Lake } \\
\text { Chincholi, Dist. } \\
\text { Bhandara }\end{array}$ & $\begin{array}{l}\text { This area is remote and most of covered by dense forest covers. The first roost was recorded } \\
\text { by us in Chicholi village at Chicholi Lake, on impoundment, road side and around agriculture } \\
\text { field. On four mango trees, about } 360 \text { bats were counted. Chicholi site roost existing last from } \\
50 \text { years and is situated near Bhondki forest area. No special threats occurred. }\end{array}$ \\
\hline 9 & $\begin{array}{l}\text { Sundartola Toli, } \\
\text { Dist. Bhandara, } \\
\text { MS }\end{array}$ & $\begin{array}{l}\text { The roost is on the waste land on two Arjun trees. About } 175 \text { bats were counted during study } \\
\text { period. No specific anthropogenic threat occurs, but some disturbances occur due to encroach- } \\
\text { ment on bare land. The adjacent areas are lake and road side. The site is established about } 50 \\
\text { years ago. }\end{array}$ \\
\hline 10 & $\begin{array}{l}\text { Asalpani Amrai, } \\
\text { Dist. Bhandara }\end{array}$ & $\begin{array}{l}\text { No specific threat to the site but road activities disturbing the roost. We motivate local people } \\
\text { to help to conserve them. }\end{array}$ \\
\hline 11 & $\begin{array}{l}\text { Itiadoh Dam Res- } \\
\text { ervoir, Dist. } \\
\text { Gondia }\end{array}$ & $\begin{array}{l}\text { The trend of population size of the roost showed an increasing trend during the study period. } \\
\text { The site is far away from the human habitation but some time. The roost was disturbed by the } \\
\text { tourists. The ban on activities by Tourists will help to manage this population and conserve } \\
\text { them. }\end{array}$ \\
\hline 12 & $\begin{array}{l}\text { Wadegao Keshori } \\
\text { Dist. Gondia }\end{array}$ & $\begin{array}{l}\text { People were surprisingly commented with negative approach. Some habitats were destructed } \\
\text { due to their noisy sound. The flock of } 300 \text { bats was drive away by villagers many times. Con- } \\
\text { servation of such tall mango tree is essential. }\end{array}$ \\
\hline 13 & $\begin{array}{l}\text { Chutia, Dhabe } \\
\text { Pauni } \\
\text { Navegao National } \\
\text { Park, Dist. Gondia }\end{array}$ & $\begin{array}{l}\text { It is situated in dense forest region of Navegaon National park, it is protected. About } 100 \text { bats } \\
\text { were killed in acute mass death, reported in } 2009 \text { due to extreme heat wave. Some anecdotal } \\
\text { information of evidences of poaching of bats occurred. }\end{array}$ \\
\hline 14 & $\begin{array}{l}\text { Baghnadi, Chattis- } \\
\text { garh, Near Gondia } \\
\text { district }\end{array}$ & $\begin{array}{l}\text { There are total } 07 \text { tree in the dense vegetation was occupied by bats as roost. In the prelimi- } \\
\text { nary observation bats disturbed some time from the loud sound by visitors while playing and } \\
\text { cooking activities. According to some anecdotal information as well as warden and official of } \\
\text { department also stated that the population of this bat was more than three thousand in this site } \\
\text { before three to four year ago. Electrocution is major threat. }\end{array}$ \\
\hline 15 & $\begin{array}{l}\text { Market lake Bram- } \\
\text { hapuri, Dist. } \\
\text { Chandrapur }\end{array}$ & $\begin{array}{l}\text { The bats were observed in } 2014 \text {. The roost is situated in the market placed, always found dis- } \\
\text { turbed. The roost is not safe for further proliferation of the population. The roost will be disap- } \\
\text { pearing in near future. }\end{array}$ \\
\hline
\end{tabular}

Table 1: Roost wise ecological notes and threats

the benefits occurring due to their seed spreading habits. The disturbance to traditional roosts has resulted in bats finding alternate roosts nearby or farther away (Molur And Walker, 1998). Therefore the conservation of the roost tree is essential. If we conserve the habitat or IFF, we may conserve our nature through natural propagation of the seed plants. For further conservation of the roost habitat the Government must take decision towards this. The plantation of indigenous and religious plant is essential that IFF can harbor their family with succession. The thorough nurturing of IFF is essential from the childhood education, it need some fact stories must be included 


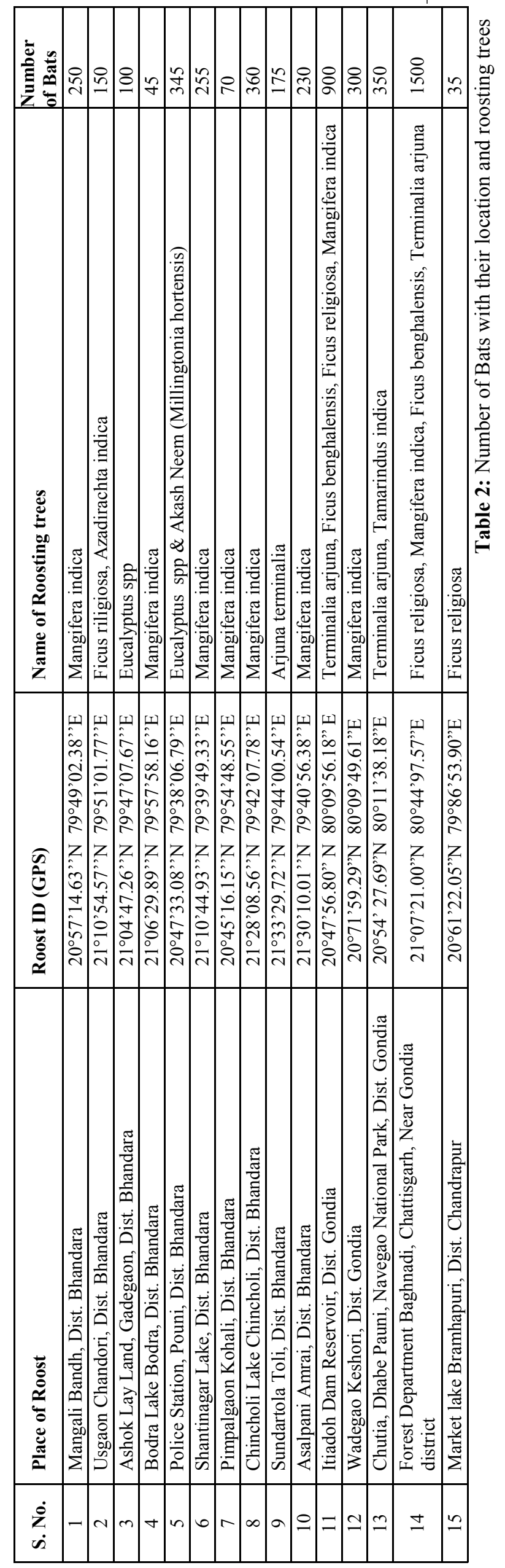

in the syllabus from higher secondary education. Last but not the least, Research on population ecology and its scientific documentation is essential for further conservation.

\section{Acknowledgement}

Thankful to the Volunteers of SENSE \& AWF and Grateful to officials of ENVIS Maharashtra for their valuable support.

\section{References}

Bhandarkar, S. V. and Paliwal, G. T. (2013a): Ecology of Indian Flying Foxes in Eastern Vidarbha Region with Reference to Their Conservation Efforts. Published in National conference on 'Recent trends in biodiversity conservation and Management'. Indian Streams Research Journal, 96-99.

Bhandarkar S. V. and Paliwal G. T. (2013b): Preliminary Observation on Acute Mass Death of Indian Flying Fox in Eastern Maharashtra India. Journal of Science Information, 6:2829.

Bhandarkar, S. V. and Paliwal, G. T. (2014): Population and Conservation Status of the Indian Flying fox roost in Itiadoh dam, MH. Small Mammal Mail, CCINSA and RISCINSA, 6 (1):15-18.

Bhandarkar, S. V. and Paliwal, G. T. (2017): A Record of Giant Roost of Pteropus Gigantius (Brunnich, 1782) In Baghnadi District Rajnandgaon Chhattisgarh. International Journal of Advance and Innovative Research, 4.4 (1):33-36.

IUCN (2008): http://dx.doi.org/10.2305/ IUCN.UK.2008.RLTS.T18725A8511108.en

Mistry, S. (2000): Tropical Ecosystems: Structure, Diversity and human welfare. In: Ganeshiash, K. S.; Umashankar R. and Bawa, K. S. (Eds.) Proceedings of the International Conference on tropical Ecosystems, oxford-IBH, New Delhi, 707-710.

Molur, S. and Walker, S. (1998): Conservation Assessment and Management Plan (C.A.M.P.) workshop. Mammals of India report summary. Zoo Outreach organization, India. 